\title{
Fitting nonlinear autoregressive models to describe coffee seed germination
}

\author{
Ajuste de modelos não lineares autorregressivos na descrição da germinação \\ se sementes de café \\ Iábita Fabiana Sousa ${ }^{I}$ Johan Eugen Kunzle Neto' ${ }^{\text {II }}$ Joel Augusto Muniz ${ }^{\text {III }}$ \\ Renato Mendes Guimarães ${ }^{I I}$ Taciana Villela Savian ${ }^{I}$ Fabiana Rezende Muniz ${ }^{I}$
}

\begin{abstract}
Cumulative germination of coffee has a longitudinal behavior mathematically characterized by a sigmoidal model. In the seed germination evaluation, the study of the germination curve may contribute to better understanding of this process. The aim of this study was to evaluate the goodness of fit of Logistic and Gompertz models, with independent and first-order autoregressive errors structure, AR (1), in the description of coffee (Coffea arabica L.) line Catuai vermelho IAC 99 germination, at five different potential germination. The data used were from an experiment conducted in 2011 at the Seed Analysis Laboratory of the Federal University of Lavras. The Logistic and Gompertz nonlinear models were appropriately adjusted to the percentage germination data. The Gompertz model with first-order autoregressive errors structure was the best to describe the germination process.
\end{abstract}

Key words: growth models, Autocorrelated errors, Nonlinear regression, Germination potential, Regression and correlation.

\section{RESUMO}

A germinação acumulada de sementes de café tem um comportamento longitudinal matematicamente caracterizado por um modelo sigmoidal. Na avaliação de sementes, o estudo da curva de germinação pode contribuir para melhor entendimento de tal processo. O objetivo deste estudo foi avaliar a qualidade do ajuste dos modelos Logístico e Gompertz, com estrutura de erros independentes e autorregressivos de primeira ordem, AR(1), na descrição de germinação de sementes de café (Coffea arabica L.), linhagem Catuaí vermelho IAC 99, em cinco diferentes potenciais de germinação. Os dados utilizados foram provenientes de um experimento conduzido no ano de 2011 no Laboratório de Análises de Sementes da Universidade Federal de Lavras. Os modelos não lineares Logístico e Gompertz se ajustaram adequadamente aos dados de porcentagem de germinação acumulada. $O$ modelo
Gompertz com estrutura de erros autorregressivos de primeira ordem apresentou-se como o melhor para descrever o processo germinativo ao longo do tempo.

Palavras-chave: modelos de crescimento, erros autocorrelacionados, regressão não linear, potencial de germinação, regressão $e$ correlação.

\section{INTRODUCTION}

Seed germination is a sequence of physiological events influenced by external and internal factors, where each factor can act by itself or in interaction with others (NASSIF et al., 1998; FLORIANO, 2004). The cumulative germination of seeds, as well as other biological phenomena, generally has a longitudinal behavior mathematically characterized by a sigmoidal model. It has an increasing function at early stages of development and then an increase of lesser intensity, which sometimes shows stability. The identification and separation of these phases become important since each phase can have different biological interpretations (MAZZINI et al., 2003; TERRA et al., 2010).

Sigmoidal curves, also known as growth models, have wide application in agricultural research (MENDES et al., 2008; TERRA et al., 2010; DERAKHSHAN \& GHEREKHLOO, 2013) and can be evaluated by means of nonlinear models,

IEscola Superior de Agricultura Luiz de Queiroz (ESALQ), Universidade de São Paulo (USP), Piracicaba, SP, Brasil.

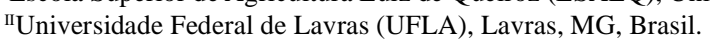

IIIDepartamento de Ciências Exatas, UFLA, 37200-000, Lavras, MG, Brasil. E-mail: joamuniz@ufla.br. Autor para correspondência. Received 10.09.13 Approved 03.04.14 Returned by the author 07.30.14 CR-2013-1341.R1 
wich operates through data modelling by a nonlinear combination of parameters depending on one or more independent variables. Several models have been proposed for modeling growth curves, such as Logistic, Gompertz, Von Bertalanffy, Richards and Weibull (RATKOWSKY, 1983; ESPIGOLAN et al., 2013). In many cases these models have their specific functional form according to the treated problem, related to some mechanism inherent to the specific process.

Nonlinear Logistic and Gompertz models are suitable for the description of seed germination, since they estimate the maximum percentage of accumulated germination (GASPAR-OLIVEIRA et al., 2008; TOMAZ et al., 2010), the time and the speed to achieve the maximum germination potential and have good fit.

In studies of germination curves some important statistical assumptions must be taken into consideration, such as the variance heterogeneity of seed germination in time course and the existence of autocorrelation between the residuals of the fit. Therefore, the failure to consider the assumptions associated with the model can lead to biased estimates and underestimation of the parameters variances.

The present research aimed to evaluate the goodness of fit of the Logistic and Gompertz nonlinear models, to data of seed germination of $\boldsymbol{C}$. arabica cultivar 'Catuaí vermelho IAC 99', across a range of germination rates.

\section{MATERIAL AND METHODS}

The research was conducted from September $6^{\text {th }}$ to October $6^{\text {th }}, 2011$, in the Seed Analysis Laboratory (LAS) of the Department of Agriculture (DAG), Federal University of Lavras (UFLA), in Lavras, MG. Five lots (I-V) of coffee were used, with minimum germination potential of $73 \%, 88 \%, 90 \%, 90 \%$ and $97 \%$, respectively. The intention was to work with different potentials to examine whether these parameters affect germination curves. Each treatment consisted of four replicates of 100 seeds each, using paper towel rolls (germitest) as substrate, moistened with distilled water in the ratio of 2.5 times the weight of the dry paper, placed in germination chamber at $30^{\circ} \mathrm{C}$ (MAPA, 2009). Seed germination was monitored each day for 30 days, using root protrusion as the criterion of germination.

Logistic (M1) and (M2) and Gompertz (M3) and (M4) nonlinear models, with independent and autoregressive errors of first-order AR (1), were fitted to the percentage germination data, respectively, expressed as follow (SEBER \& WILD, 1989).

$$
\begin{aligned}
& Y_{t}=\frac{\exp [-\gamma(X-\beta)]}{1+u_{t}} \\
& Y_{t}=\frac{+\exp [-\gamma(X-\beta)]}{1}+\phi u_{t}+\xi_{t} \\
& Y_{t}=\alpha \exp \left[-\exp \left(\gamma\left(X_{t}-\beta\right)\right)\right]+u_{t} \\
& Y_{t}=\alpha \exp \left[-\exp \left(\gamma\left(X_{t}-\beta\right)\right)\right]+\phi u_{t-1}+\xi_{t}
\end{aligned}
$$

where:

$Y_{t}$ - cumulative germination percentage at time t; $\alpha$ - represents the highest cumulative germination percentage, stabilizing value of $Y$ with respect to time $\mathrm{t} ; \beta$ - time at which $Y$ reaches half of its maximum value at the Logistic model and approximately $37 \%$ of its maximum value at the Gompertz model; $\gamma$ growth rate, which represents the germination rate to reach the asymptotic value; exp - base of the neperian logarithm; $X_{t}$ - time required for seeds germination, given in days, $t=1,2,3, \ldots, 30 ; u_{t}$ residue at time $\mathrm{t} ; u_{t-1}$ - residue at time $\mathrm{t}-1 ; \phi$ - the first-order autoregressive parameter; $\xi$ - white noise of the Normal distribution $\mathrm{N} \sim\left(0, \sigma^{2}\right)$, for independent errors structure $\xi_{t}=u_{t}$.

Parameter estimates of nonlinear models (with and without autoregressive error) were obtained using the generalized least squares method, considering the variance heterogeneity and/or residual auto-correlation (HOFFMAN \& VIEIRA, 1998; MAZZINI et al., 2005). The least squares estimates of the parameters were obtained using the Gauss-Newton iterative method and performing residual regression by first derivatives of nonlinear model parameters, until convergence was achieved (SAVIAN \& MUNIZ, 2007). The most parsimonious model to describe germination was identified using the accuracy of adjustments according to the following criteria (ZEVIANI et al., 2012): adjusted coefficient of determination $\left(R_{a j}^{2}\right)$ - the larger was the value of $R_{a j}^{2}$, better was the model; Residual Standard Deviation (RSD) - the lower was the RSD, better was the fitted model; the Akaike's Information Criterion (AIC); the Bayesian Information Criterion (BIC); and Likelihood Ratio Test (LRT). After adjustment of Logistic and Gompertz models, the residues analysis was proceeded based on the statistics of Shapiro-Wilk test for normality, and Dubin-Watson for error independence, adopting a significance level of $5 \%$. 
Residual analysis was performed through statistical tests. The adjustment procedures for models with independent and correlated error structures were implemented using gnls function (adequacy of the linear model using generalized least squares) of the nlme package (linear and nonlinear models of mixed effects) in the $\mathrm{R}$ program (version 2.13.1) (PINHEIRO et al., 2014). For the residues analysis of nonlinear regression, methods that can be adjusted in $\mathrm{R}$ were used as the gradient matrix of the model set in the function $\mathrm{lm}$. Initial values were obtained using an iterative graphical method to initial values in a nonlinear regression.

\section{RESULTS AND DISCUSSION}

It was found in all analyzed lots the lack of normality $(\mathrm{P}<0.003)$ and in some situations such as fitting the Logistic model for seeds of lot I $(\mathrm{P}<0.001)$ and the Gompertz model for seeds of lots I, II, III and IV $(\mathrm{P}<0.004)$, was also checked the violation of the assumption of residual independence, indicating the need for appropriate corrective actions to validate the fitted models.

In the study of nonlinear models that describe plant growth it is quite reasonable to incorporate autocorrelation, given that the growth measures are taken in the same experimental unit. PRADO et al. (2013), in a study on the adjustment of Logistic and Gompertz models on fruit growth data of dwarf coconut identified residual autocorrelation for both variables analyzed and, when considering the autoregressive process for the modeling, it was obtained more precise estimates. PEREIRA et al. (2005), in a study on the prediction of mineralized nitrogen in oxisol by using nonlinear models, incorporated the residual autocorrelation and found more precise parameters estimates. MAZZINI et al. (2005) and MENDES et al. (2008) analyzing growth of beef cattle, and GUEDES et al. (2004) evaluating averaged data of lambs, observed a higher goodness of fit for models that incorporated autoregressive parameters. After implementation of appropriate corrective measures, a new estimation was done following a new residual diagnosis with normal distribution. In table 1 , the statistic of the maximum likelihood ratio test is presented for Logistic and Gompertz models. For the logistic model, only for lot I, LRT identified a best fit to the data, considering the correlated residues AR (1). However with the Gompertz model in all lots, the best fit presented structure of errors AR (1).
Table 1 - Statistics of the Likelihood Ratio Test (LRT) for Logistic and Gompetz models, with errors structure AR (1), in lots of different germination potential.

\begin{tabular}{lll}
\hline \multirow{2}{*}{$\begin{array}{l}\text { Germination } \\
\text { Potential }\end{array}$} & Logistic AR(1) & Gompertz AR(1) \\
\hline I & $9.8417^{* * *}$ & $25.8619^{*} * *$ \\
II & $1.5556^{\mathrm{NS}}$ & $9.3801 * * *$ \\
III & $0.3875^{\mathrm{NS}}$ & $11.3910^{* * *}$ \\
IV & $1.1529^{\mathrm{NS}}$ & $22.9725^{* * *}$ \\
$\mathrm{~V}$ & $1.0140^{\mathrm{NS}}$ & $3.9992^{*} *$ \\
\hline
\end{tabular}

** values significant at $1 \%(\mathrm{P}<0.01)$. $*$ values significant at $5 \%$ $(\mathrm{P}<0.05)$. NS values non-significant.

The Gompertz model with structure of errors AR (1) showed a better fit to the data, evidenced by lower values for the criteria RSD, AIC and BIC. The adjusted coefficients of determination $\left(\mathrm{R}^{2}{ }_{\mathrm{aj}}\right)$ showed similar results, all above $99 \%$, not satisfied the choice of the best model by this statistic (Table 2 ).

The seeds lots showed similar highest cumulative germination percentage $(\alpha)$, being all estimates above $90 \%$ (Table 3 ). With the exception of lot $\mathrm{V}$, the estimated percentages were superior to the minimum percentages used in the classification of the lots, with the largest difference found for lot I, which the minimum percentage of germination was $73 \%$ and in fact germinated $93.23 \%$, with an increase of $27.6 \%$. Lots III and IV had equal minimum percentage of germination and differed slightly, with a small advantage for Lot IV. The parameter $(\beta)$ is related to the day that accumulated germination reaches approximately $40 \%$ of the maximum cumulative germination. Lot $\mathrm{V}$ obtained the shortest time to reach the germination potential, which may be related to the high power of seeds germination. Parameter $(\gamma)$, representing the speed of germination, had on lot $\mathrm{V}$ the highest estimated value, which indicates that the cumulative germination percentage was reached in a shorter time than the other qualities studied. Estimates of the standard errors of the parameters $(\alpha, \beta, \gamma)$ decreased significantly when considering the autoregressive process. On lot I, for example, the decrease ranged around $37 \%, 45 \%$ and $41 \%$, respectively. Similar results were presented by PRADO et al. (2013), MELO et al. (2011) and MENDES et al. (2008), who considered the autoregressive structure and obtained more precise estimates.

Regarding the first order autoregressive parameter $\left(\phi_{1}\right)$, the error associated with the seeds germination rate on a date is negatively correlated with the error of the earlier date. AGR were increased until 
Table 2 - Estimates of selection criteria: adjusted coefficient of determination $\left(\mathrm{R}_{\text {aj }}^{2}\right.$ ), residual standard deviation (RSD), Akaike's information criterion (AIC) and Bayesian Information Criterion (BIC) for the adjusted models.

\begin{tabular}{|c|c|c|c|c|c|}
\hline \multirow{2}{*}{ Lots } & \multirow{2}{*}{ Models } & \multicolumn{4}{|c|}{ 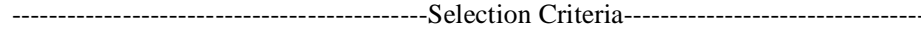 } \\
\hline & & $\mathrm{R}_{\mathrm{aj}}^{2}$ & RSD & AIC & BIC \\
\hline \multirow{4}{*}{ I } & Logistic & 0.99995 & 2.1329 & 135.4249 & 141.0297 \\
\hline & Gompertz & 0.99998 & 2.1422 & 135.6855 & 141.2903 \\
\hline & Logistic AR(1) & 0.99995 & 2.1122 & 127.5831 & 134.5891 \\
\hline & Gompertz AR(1) & 0.99999 & 2.0609 & 111.8236 & 118.8296 \\
\hline \multirow{4}{*}{ II } & Logistic & 0.99975 & 2.3135 & 140.3023 & 145.9071 \\
\hline & Gompertz & 0.99999 & 1.4631 & 112.8095 & 118.4143 \\
\hline & Logistic AR(1) & 0.99968 & 2.3187 & 140.7467 & 145.7527 \\
\hline & Gompertz AR(1) & 0.99999 & 1.4477 & 105.4295 & 112.4355 \\
\hline \multirow{4}{*}{ III } & Logistic & 0.99974 & 2.7985 & 151.7209 & 157.3257 \\
\hline & Gompertz & 0.99999 & 2.0910 & 134.2351 & 139.8399 \\
\hline & Logistic AR(1) & 0.99978 & 2.7977 & 153.3334 & 160.3394 \\
\hline & Gompertz AR(1) & 0.99999 & 2.0613 & 124.8441 & 131.8500 \\
\hline \multirow{4}{*}{ IV } & Logistic & 0.99986 & 1.9117 & 128.8573 & 134.4651 \\
\hline & Gompertz & 0.99999 & 1.3780 & 109.2151 & 114.8199 \\
\hline & Logistic AR(1) & 0.99987 & 1.9111 & 130.1595 & 137.1655 \\
\hline & Gompertz AR(1) & 0.99999 & 1.3119 & 882.426 & 952.486 \\
\hline \multirow{4}{*}{ V } & Logistic & 0.99991 & 1.4915 & 113.9644 & 119.5692 \\
\hline & Gompertz & 0.99999 & 0.6221 & 615.024 & 671.077 \\
\hline & Logistic AR(1) & 0.99965 & 2.0397 & 114.9503 & 121.9563 \\
\hline & Gompertz AR(1) & 0.99999 & 0.6306 & 595.031 & 665.091 \\
\hline
\end{tabular}

reaching the maximum of $28 \%$ day $^{-1}$ for lot I, about $21 \%$ day $^{-1}$ for lot II, $23 \%$ day $^{-1}$ for lot III, $26 \%$ day $^{-1}$ for lot IV and $35 \%$ day $^{-1}$ for lot V. At this stage, the germination rate was high and positive, reaching a maximum at the inflection point of the curve, which occurred near the $9^{\text {th }}$ day. From this point, the concavity of the curve changes and the germination rate starts to decrease exponentially due to factors that gradually inhibit the germination. It is noted that lot V, characterized as the best germination potential, had a shorter time

Table 3 - Parameters estimates for fitting Gompertz model, with structures of autoregressive first-order errors, to the seed percentage germination data for the five lots.

\begin{tabular}{llrcc}
\hline & & & \\
Lost & - & & & \\
& $\alpha$ & $\beta$ & $\gamma$ & $\phi_{1}$ \\
\hline I & 93.23 & 9.69 & 0.85 & -0.74 \\
II & 93.08 & 9.49 & 0.66 & -0.51 \\
III & 96.52 & 10.01 & 0.63 & -0.55 \\
IV & 95.47 & 9.32 & 0.78 & -0.72 \\
V & 97.26 & 8.61 & 1.01 & -0.39 \\
\hline
\end{tabular}

for germination process, since in the thirteenth day virtually all the seeds had already germinated (Figure 1). In general, these results corroborate with EIRA et al. (2006), about the physiology and germination of coffee seed, in which on the tenth day $50 \%$ of coffee seeds showed root protrusion, and on the fifteenth day most seeds have already germinated.

It was noted that both models adequately describe seed germination, with curves very close to the observed values, but highlighting the Gompertz model considering the structure of autocorrelated errors of order 1 (Figure 2).

\section{CONCLUSION}

Germination of coffee is described by Logistic and Gompertz nonlinear models, presenting adequate biological interpretation of the parameters. Gompertz model with first-order autoregressive errors structure fits more appropriately to describe the percentage of cumulative germination of coffee seeds, when compared to the Logistic model, being the most suitable model. According to the adjustment, germination phases over time were well established. 

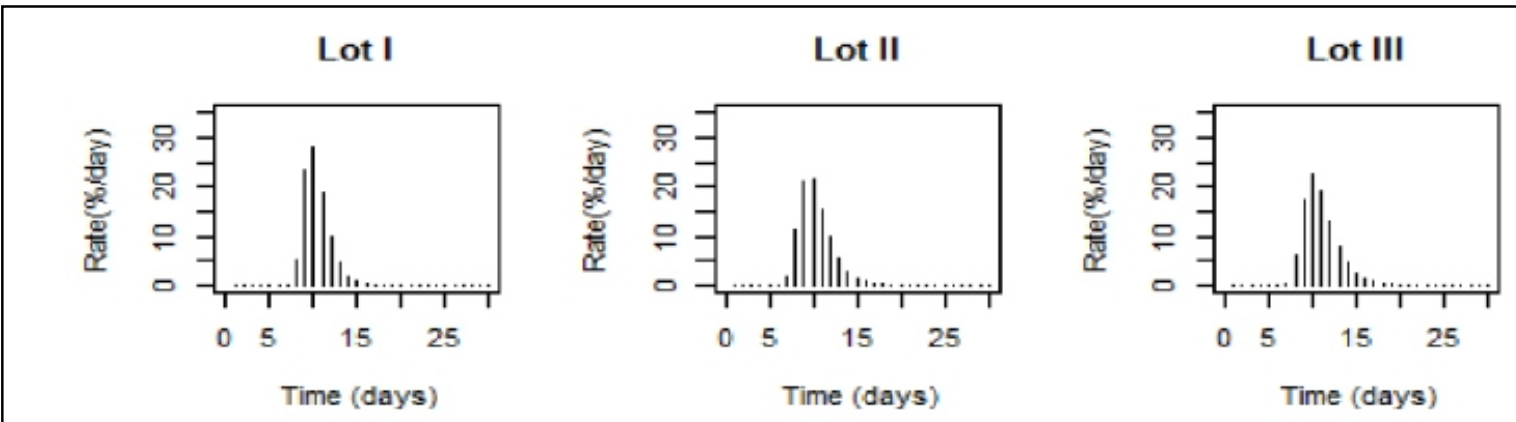

Lot IV

\section{Lot V}
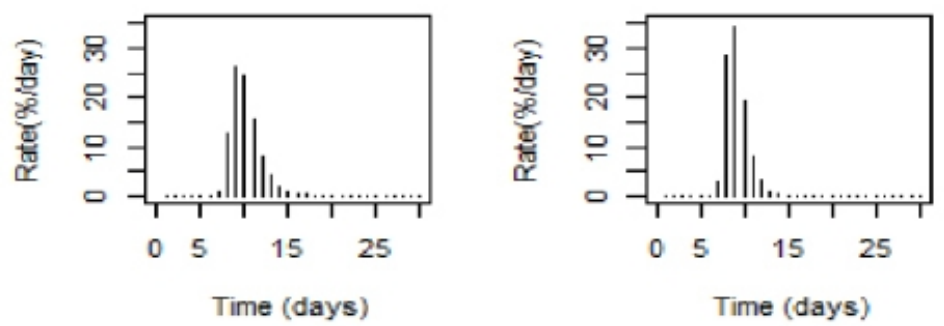

Figure 1 - Representative histogram of absolute germination rate (AGR) of coffee seeds estimated by the Gompertz function in the five seed lots.
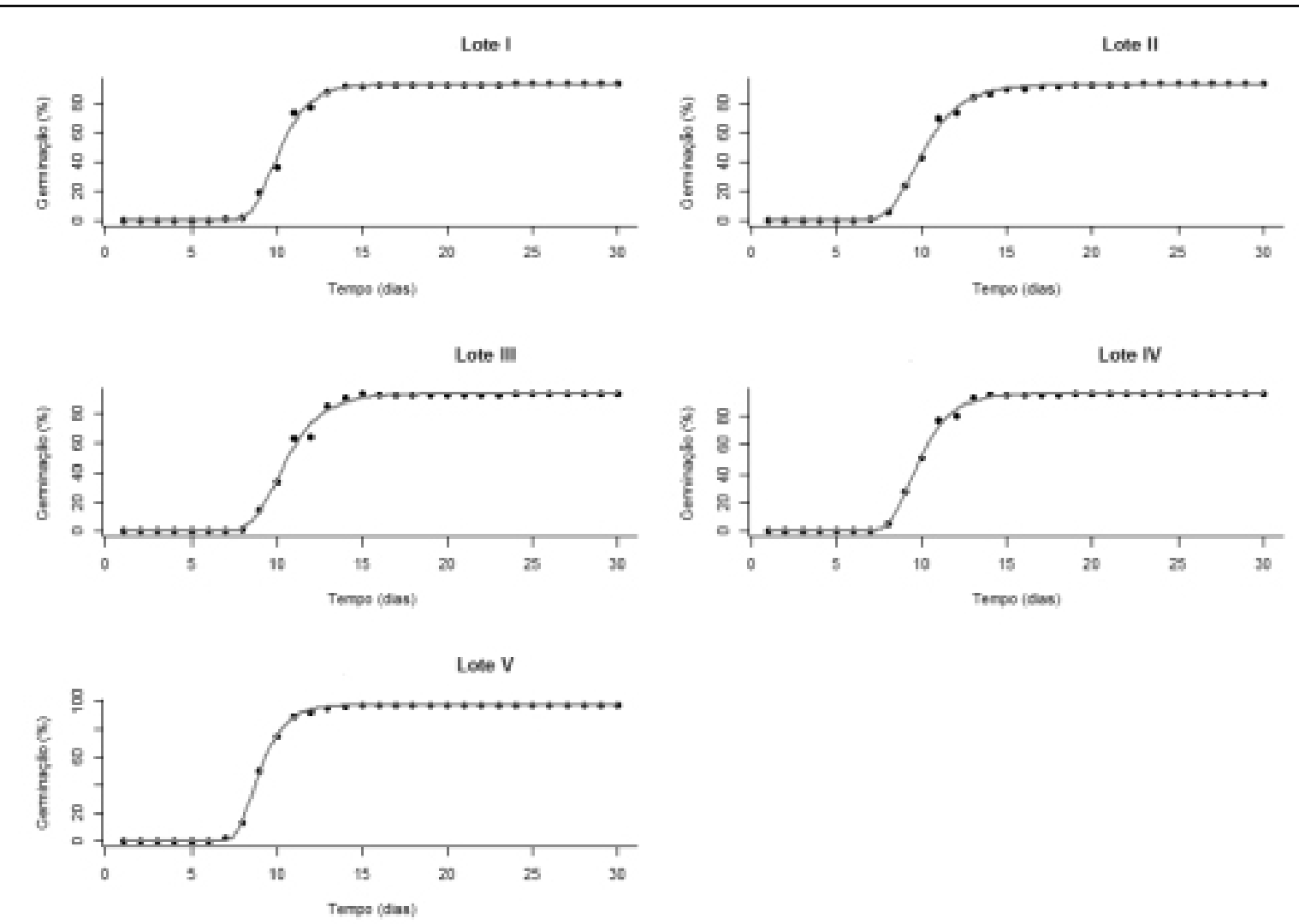

Figure 2 - Mean values of accumulated germination percentage from fitting curve of Gompertz model, with errors structures AR (1) for the five seed lots. 


\section{ACKNOWLEDGEMENTS}

Thanks to Coordenação de Aperfeiçoamento de Pessoal de Nível Superior (CAPES) and Universidade Federal de Lavras (UFLA) for financial and technical supports.

\section{REFERENCES}

DERAKHSHAN, A.; GHEREKHLOO, J. Factors affecting Cyperus difformis seed germination and seedling emergence. Planta daninha, Viçosa, v.31,n.4, p.823-832, 2013. Available from: $<$ http://www.scielo.br/scielo.php?pid=S0100-835820130004 00008\&script=sci_arttext $>$ Accessed: Dec. 20, 2013. doi: 10.1590/ S0100-83582013000400008.

EIRA,M.T.etal. Coffee seed physiology. BrazilianJournal of Plant Physiology, Londrina, v.18, n.1, p.149-163, 2006. Available from: <http://www.scielo.br/scielo.php?script=sciarttext\&pid=S 167 704202006000100011>. Accessed: Dec. 18, 2011. doi: 10.1590/ S1677-04202006000100011.

ESPIGOLAN, R. et al. Aplicação de modelos não lineares para descrever a evolução de características de crescimento e carcaça em bovinos da raça Hereford. Ciência Rural, Santa Maria, v.43, n.3 p.513-519, 2013. Available from: <http://www.scielo.br/scielo. php?script=sci_arttext $\&$ pid $=$ S0103-84782013000300023\&lng $=$ pt\&nrm=iso\&tlng=en>. Accessed: Jan. 18, 2013. doi: 10.1590/ S0103-84782013005000011.

FLORIANO, E.P. Germinação e dormência de sementes florestais Santa Rosa: ANORGS, 2004. 19p. (Caderno didático n.2).

GASPAR-OLIVEIRA, C.M. et al. Duração do teste de germinação de Brachiaria brizantha cv. 'marandu' (Hochst. ex A. Rich.) Stapf. Revista Brasileira de Sementes, Londrina, v.30, n.3, p.30-38, 2008. Available from: <http://www.scielo.br/pdf/rbs/ v30n3/05.pdf>. Accessed: Dec. 18, 2013. doi: 10.1590/S010131222008000300019 .

GUEDES, M.H.P. et al. Estudo das curvas de crescimento de cordeiros das raças Santas Inês e Bergamácia: considerando heterogeneidade de variâncias. Ciência e Agrotecnologia, Lavras, v.28, n.2, p.381-388, 2004. Available from: <http://www.scielo. br/pdf/cagro/v28n2/a19.pdf>. Accessed: Dec. 18, 2013. doi: 10.1590/S1413-70542004000200019.

HOFFMAN, R.; VIEIRA, S. Análise de regressão: uma introdução à econometria. São Paulo: HUCITEC, 1998. 379p.

MAPA. MINISTÉRIO DA AGRICULTURA PECUÁRIA E ABASTECIMENTO. Regras para análise de sementes. Brasília: Secretaria de Defesa Agropecuária, Mapa, 2009. 398p.

MAZZINI, A.R. de A. et al. Curva de crescimento de novilhos Hereford: heterocedasticidade e resíduos autorregressivos. Ciência Rural, Santa Maria, v.35, p.422-427, 2005. Available from: <http://www.scielo.br/scielo.php?pid=S0103847820050002000 28\&script $=$ sci_arttext $>$. Accessed: Jan. 18, 2012. doi: 10.1590/ S0103-84782005000200028.

MAZZINI, A.R. de A. et al. Análise da curva de crescimento de machos Hereford. Ciência e Agrotecnologia, Lavras, v.27, n.5, p.1105-1112, 2003. Available from: <http://www.scielo.br/ scielo.php?script $=$ sci_arttext $\&$ pid $=S 1413-70542003000500019>$. Accessed: Jan. 21, 2012 doi: 10.1590/S1413-70542003000500019.
MELO, A.L.P. et al. Identificação e modelagem da autocorrelação residual no ajuste do modelo de Wood às curvas de lactação de cabras. Ciência Rural, Santa Maria, v.41, n.10, p.1818-1822, 2011. Available from: <http://www.readcube.com/articles/10.1590/ S0103-84782011001000024?locale=en>. Accessed: Jan. 03, 2014.

MENDES, P.N. et al. Modelo logístico difásico no estudo do crescimento de fêmeas da raça Hereford. Ciência Rural, Santa Maria, v.38, n.7, p.1984-1990, 2008. Available from: $<$ http://www.scielo.br/scielo.php?pid=S0103-847820080 $00700029 \&$ script $=$ sci_abstract\&tlng=pt $>$. Accessed: Jan. 21, 2012. doi: 10.1590/S0103-84782008000700029.

NASSIF, S.M.L. et al. Fatores externos (ambientais) que influenciam na germinação de sementes. Informativo Sementes IPEF - Abril 1998. Available from: <http://www.ipef.br/ tecsementes/ger minacao.asp>. Accessed: Jun. 17, 2013.

PEREIRA, J.M. et al. Nonlinear models to predict nitrogen mineralization in an Oxisol. Scientia Agricola, Piracicaba, v.62, n.4, p.395-400, 2005. Available from: <http://www.scielo.br/ scielo.php?pid $=$ S010390162005000400014\&script $=$ sci_arttext $>$. Accessed: Nov. 22, 2011. doi: 10.1590/S0103-90162005000400014.

PINHEIRO, J.C. et al. nlme: linear and nonlinear mixed effects models. Vienna: R Development Core Team, 2014. 335p.

PRADO, T.K.L. do et al. Ajuste dos modelos Gompertz e Logístico aos dados de crescimento de frutos de coqueiro anão verde. Ciência Rural, Santa Maria v.43, n.5, p.803-809, 2013. Available from: <http://www.scielo.br/pdf/cr/2013nahead/a13313cr5976.pdf >. Accessed: May 22, 2013. doi: 10.1590/S0103-84782013005000044.

RATKOWSKY, D.A. Nonlinear regression modeling: A unified practical approach. New York, Marcel Dekker, 1983. 276p.

SAVIAN, T.V.; MUNIZ, J.A. A study of in situ degradability: heterogeneity of variances and correlated errors. Scientia Agricola, Piracicaba, v.64, n.5, p.548-554, 2007. Available from: <http://www.scielo.br/scielo.php?script=sci_arttext\&pid =S0103-90162007000500013>. Accessed: Nov. 05, 2011. doi: $10.1590 /$ S0103-90162007000500013.

SEBER, G.A.F.; WILD, C.J. Nonlinear regression. New York: John Wiley, 1989. 792p.

TERRA, M.F. et al. Ajuste dos modelos Logístico e Gompertz aos dados de crescimento de frutos da tamareira-anã (Phoenix roebelenii O'BRIEN). Magistra, Cruz das Almas, v.22, n.1, p.01-07, 2010. Available from: <http://pt.scribd.com/doc/92170015/1-Ajuste-DosModelos-Logstico-e-Gompertz-Aos-Dados-de-Crescimento-deFrutos-Da-Tamareira-An-Phoenix-Roebelenii-Obrien>. Accessed: Jan. 03, 2014. doi: 10.1590/S0103-84782013005000044.

TOMAZ, C.A. et al. Duração do teste de germinação do capimtanzânia. Revista Brasileira de Sementes, Londrina, v.32, n.4, p.80-87, 2010. Available from: <http://www.scielo.br/pdf/rbs/ v32n4/09.pdf $>$. Accessed: Jan. 03, 2014. doi: 10.1590/S010131222010000400009

ZEVIANI, W.M. et al. Modelos não lineares para a liberação de potássio de estercos animais em latossolos. Ciência Rural, Santa Maria, v.42, n.10, p.1789-1796, 2012. Available from: <http:// www.scielo.br/scielo.php?pid=S00384782012001000012\&scri $\mathrm{pt}=$ sci_arttext $>$. Accessed: Apr. 06, 2012. doi: 10.1590/S010384782012001000012

Ciência Rural, v.44, n.11, nov, 2014. 